Natalia Marek

\title{
KOBIETY, RÓŻNICA SEKSUALNA I FEMINIZM. NOTATKI NA MARGINESIE ŽIŽKA
}

\section{WPROWADZENIE}

Slavoj Žižek zasłynął jako filozof, można powiedzieć, wszechstronny. Jest on bowiem jednym z głównych komentatorów i interpretatorów Lacana, marksistą (Rewolucja u bram. Pisma Lenina z roku 19171), heglistą, krytykiem filmowym (np. Enjoy Your Symptom! ${ }^{2}$ ) oraz komentatorem świata współczesnego ( $W$ obronie przegranych spraw ${ }^{3}$ ). Na pierwszy rzut oka jego poglądy i interpretacje oraz on sam są przede wszystkim kontrowersyjne i zabawne, a przez to traktowane przez innych z przymrużeniem oka. Jednak największym problemem, jaki napotyka czytelnik, jest brak widocznych różnic między jego poglądami a myślą Jacquesa Lacana. Większość tekstów zlewa się ze sobą, co jednak nie zmienia faktu, że interpretacje Žižka są niezwykle istotne dla współczesnej psychoanalizy ${ }^{4}$, filozofii i kultury. Używa on bowiem Lacana do interpretacji całej rzeczywistości, co

${ }^{1}$ S. Žižek, Rewolucja u bram. Pisma Lenina z roku 1917, Krytyka Polityczna, Warszawa 2007.

${ }^{2}$ Tenże, Enjoy Your Symptom, Routlege, Nowy Jork 1992.

${ }^{3}$ Tenże, W obronie przegranych spraw, Krytyka Polityczna, Warszawa 2008.

${ }^{4}$ Malone zwraca uwagę, że większość psychoanalityków nie korzysta bezpośrednio z tekstów Lacana, a jedynie z ich opracowań i komentarzy (to dotyczy również feministycznych interpretacji, np. Chodorowa). Zob. K. Ror Malone, Female Rivals: Feminism, Lacan \& Žižek try to think of something new to say, „International Journal of Žižek Studies” 2008, nr 3, s. 2. 
sprawia, że Lacan nie tylko zostaje odkryty na nowo, ale także staje się niezwykle aktualny. Jednak dodatkowym problemem jest fakt, że miesza on ze sobą wszystkie możliwe teorie i nazwiska - wystarczy otworzyć skorowidz jednej z książek słoweńskiego filozofa, by zobaczyć, że jego interpretacje obejmują nie tylko Lacana, Marksa, ale również: Jane Austin, Louisa Bunuela, Churchilla, Mozarta czy Mussoliniego ${ }^{5}$.

W niniejszej pracy chciałabym przeanalizować oraz dokonać próby interpretacji i syntezy poglądów Žižka dotyczących kobiecości, różnicy seksualnej, miłości oraz feminizmu. W przypadku różnicy seksualnej będzie to przede wszystkim próba niewielkiego zarysu poglądów Jaquesa Lacana, z uwagi na wspomniane już zachodzenie na siebie poglądów tych dwóch filozofów, a raczej używanie przez Žižka teorii Lacana jako narzędzia do interpretacji. W ostatniej części chciałabym spojrzeć krytycznie na prace Žižka, by następnie dokonać próby odpowiedzi na pytanie, jaki jest stosunek słoweńskiego filozofa do feminizmu oraz jak to, co Lacan i Žižek piszą o różnicy seksualnej i kobiecości, wpływa na współczesną myśl feministyczną.

\section{KOBIETA}

Kontrowersyjności tekstów Slavoja Žižka nie trzeba udowadniać, jednak doskonałym jej przykładem jest fakt, że rozpoczyna on swoje teksty dotyczące kobiecości i kobiet, przytaczając najbardziej antyfeministyczny i mizoginiczny tekst XX wieku - Płeć i charakter ${ }^{6}$. Słoweński filozof często (wydaje się, że niejako przypadkiem) dotyka problemu kobiecości, coraz to powracając do pytań dotyczących kwestii kobiecej ${ }^{7}$. Jak już zostało powiedziane we wstępie do poniższej pracy, trudno jest zdecydowanie odróżnić poglądy Žižka od twierdzeń Lacana, dlatego też początkowe części eseju będą

${ }^{5}$ Zob. S. Žižek, Wzniosły obiekt ideologii, Wydawnictwo Uniwersytetu Wrocławskiego, Wrocław 2001, s. 272-274.

${ }^{6}$ Zob. T. Myers, Jakie są stosunki między mężczyznami a kobietami?, [w:] Žižek. Przewodnik krytyki politycznej, red. Julian Kutyła, Krytyka Polityczna, Warszawa 2009, s. 120. W niniejszym eseju do tych porównań nie będziemy się odwoływać z uwagi na jej historyczny charakter.

${ }^{7}$ Zob. K. Ror Malone, Female..., dz. cyt., s. 2. 
traktować także o poglądach Lacana na kwestię kobiet. Co zatem o kobiecości możemy powiedzieć? Jak się ona przejawia i czym jest? Poniżej przedstawię cztery sposoby pisania o kobiecości przewijające się w tekstach Lacana i Žižka.

Dwa pierwsze ujęcia kobiety dotyczą pojęcia symptomu i syntomu. W latach siedemdziesiątych Lacan zmienił swoją koncepcję symptomu i stąd też bierze się różnica w określeniu kobiety. W pierwszej koncepcji symptom był czymś głęboko negatywnym, patologicznym; był wyjątkiem, który odsyła z powrotem do podmiotu. W kolejnej natomiast, którą to dla odróżnienia Žižek nazywa syntomem (le sinthome), mamy do czynienia z czymś pozytywnym, z formą znaczeniową, za pomocą której podmiot organizuje rzeczywistość oraz stosunek do rozkoszy ${ }^{8}$.

Jak przyznaje sam Žižek, pierwszą interpretację, czyli spojrzenie na kobietę jako na symptom, można uznać za zdecydowanie antyfeministyczną. Kobieta jawi się tu jako femme fatale, która materializuje rezygnację mężczyzny z etycznego dążenia do prawdy. Nie tylko zwodzi, ale także ucieleśnia jego zbłądzenie - kiedy natomiast mężczyzna powraca do poszukiwania prawdy, kobieta znika9 . Mamy tutaj do czynienia, w przeciwieństwie do kolejnej interpretacji, z negatywną wizją kobiecości, zgodną niemalże $\mathrm{z}$ perspektywą Otto Weiningera ${ }^{10}$. Kobieta jest naznaczona niespójnością, a relacja między kobietą a mężczyzną jest radykalnie asymetryczna lub po prostu nie istnieje. Kobieta jest nie tylko symptomem upadku mężczyzny, ale przede wszystkim produktem, który objawia się jako rezultat odwrotu podmiotu (mężczyzny) od intelektu i zwrotu (a raczej zbłądzenia) w kierunku popędu seksualnego. Lacan mówi o kobiecie tylko tak, jak ona się jawi bądź jest odzwierciedlona w lustrze męskiego (logocentrycznego) dyskursu.

Žižek jednak skupia się bardziej na kolejnej interpretacji, czyli ujęciu kobiety jako syntomu (le sinthome), bazując na późniejszych pracach Lacana. $\mathrm{W}$ XX seminarium ${ }^{11}$ Lacan zmienia pojęcie symptomu na bardziej kobiece

${ }^{8}$ Zob. T. Myers, Jakie..., dz. cyt., s. 121.

9 Zob. S. Žižek, Enjoy Your Symptom, dz. cyt., s. 154.

${ }^{10}$ Zob. T. Myers, Jakie..., dz. cyt., s. 112.

${ }^{11}$ Zob. J. Lacan, On Feminine Sexuality: The Limits of Love and Knowledge: The Seminar of Jacques Lacan, Book XX, W.W. Norton, Londyn 1999. 
(feminine). Syntom jak pisze Slavoj Žižek: ,jest to szczególna patologiczna formacja posiadająca znaczenie, związana rozkosz, nieruchoma plama opierająca się komunikacji i interpretacji, plama, której nie można włączyć obieg dyskursu, w sieć więzi społecznych, ale która zarazem jest ich pozytywnym warunkiem" ${ }^{12}$. Jeżeli zatem kobieta jest syntomem mężczyzny, to jest czymś pozytywnym, czymś, co stanowi o jego istnieniu i spójności. Bez spójności podmiot by zniknął, a więc tym samym kobieta staje się warunkiem podmiotowości. Oddaje to fragment książki Wniosły obiekt ideologii:

\begin{abstract}
Aby to wyjaśnić, wystarczy tylko przypomnieć dobrze znane męskie szowinistyczne poglądy na temat kobiet, do których Freud często nawiązuje. Z kobietami trudno jest wytrzymać, są źródłem ciągłych kłopotów, zarazem jednak nie wymyślono niczego lepszego niż one. [...] Jeżeli kobieta nie istnieje, to mężczyzna jest być może po prostu kobietą, która myśli, że istnieje $e^{13}$.
\end{abstract}

Kobieta nie jest więc już tylko objawem, który przeszkadza mężczyźnie w dążeniu i odkryciu prawdy, ale byłaby wręcz jedynym warunkiem możliwości jej poznania.

Z kolejnym odmiennym od poprzedniego spojrzeniem spotykamy się w eseju Woman is One of the Names-of-the-Father, or How Not to Misread Lacan's Formulas of Sexuation ${ }^{14}$. Kobieta jawi się tu jako sprzeczność. Co wynosi Žižek z Lacanowskiego diagramu różnicy seksualnej? Otóż kobieta jest, jak wskazuje tytuł, jednym z Imion Ojca ${ }^{15}$. To, co zapewnia nam pojęcie kobiety, to mityczny punkt wyjścia pełni, której pierwotna represja konstytuuje porządek. Mamy tu do czynienia z kobietą jako punktem wyjścia, reprezentacją, obrazem, który ma fascynować i przyciągać spojrzenie; wciąż będącą tą, która jest zagadką, czymś niereprezentowanym, co a priori umyka spojrzeniu. Więcej, w tym ujęciu, kobieta niejako podkopuje uniwersalność funkcji fallicznej poprzez fakt, że nie ma w niej wyjątku, który jest obecny

${ }^{12}$ S. Žižek, Wzniosły..., dz. cyt., s. 96.

${ }^{13}$ Tamże, s. 96-97.

${ }^{14}$ Tenże, Woman is One of the Names-of-the-Father, or How Not to Misread Lacan's Formulas of Sexuation, Lacanian Ink 10, [w:] http://www.lacan.com/zizwoman.htm (dostęp: 7 IV 2012).

${ }^{15}$ Istotna jest liczba mnoga. 
w „męskiej” części diagramu ${ }^{16}$. Owszem - kobieta jej podlega, jednakże nigdy całkowicie. Zawsze zostaje coś, co odsyła w zupełnie innym kierunku, „coś”, co niejako wymyka się funkcji fallicznej, zwracając się ku Innemu (braku), wykraczając poza przestrzeń. Kobieta „nie-istnieje”.

W tym samym tekście Žižek, odwołując się do eseju Lacana The Signification of the Phallus ${ }^{17}$, ukazuje kobietę $\mathrm{w}$ jedynie pozornie odmienny sposób, jako maskę. Tu różnica seksualna, o której szerzej będzie mowa w następnej części tekstu, pojawia się jako coś wewnętrznego wobec ekonomii fallicznej, jako różnica między posiadaniem a byciem. Mężczyzna posiada fallusa, kobieta jest fallusem. Dybel pisze:

Kobieta, grając wobec mężczyzny rolę tej, która wprawdzie fallusa nie „posiada”, ale za to nim „jest”, stara się zrobić dla siebie użytek z męskiego kompleksu kastracji, manifestującego się w postaci rozziewu między jego (iluzorycznym) roszczeniem do „posiadania” fallusa a ontolo-

${ }^{16}$ Zob. http://www.lacan.com/zizwoman.htm (dostęp: 7 IV 2012):

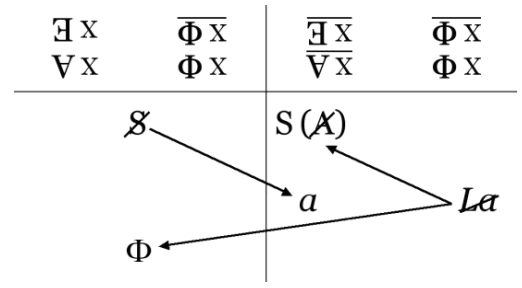

Pierwsza para, umieszczona nad lewym polem („męskim”), czytana dosłownie, znaczy: (1) „wszystkie x są podporządkowane funkcji fallicznej” oraz: (2) wszelako „jest jedno x, które nie jest podporządkowane funkcji fallicznej”. Para znajdująca się po stronie prawej („kobieca”) znaczy: (3) „nie wszystkie x są podporządkowane funkcji fallicznej” oraz: (4) wszelako „nie ma takiego x, które by nie było podporządkowane funkcji fallicznej”. Sprzeczność jest jedynie pozorna, ponieważ pozostają one wobec siebie w dialektycznym związku negacji. To zatem, co w drugim równaniu każdej pary wygląda na zaprzeczenie pierwszego, stanowi w istocie jedynie jego dialektyczne dookreślenie. Więcej o diagramie różnicy seksualnej u Lacana można przeczytać m.in. u: P. Dybel, Zagadka drugiej płci. Spór wokót różnicy seksualnej w psychoanalizie i feminizmie, Uniwersitas, Kraków 2006, s. 217-278.

${ }^{17} \mathrm{~J}$. Lacan, The Signification of the Phallus, [w:] Ecrits: The First Complete Edition in English, red. J. Lacan, W.W. Norton, Londyn 2006. 


\section{Natalia Marek}

giczną niemożnością pełnego utożsamienia się z nim. [...] Obie strony zatem, kobieta i mężczyzna, stosują podobną strategię kreowania wyobrażeniowych pozorów i na tej drodze przesłaniania własnego braku, tyle że owe „pozory" są całkiem innego rodzaju. Mężczyzna nakłada wobec kobiety maskę „pana i władcy”, kogoś, kto „wszystko wie” i może służyć jej za niezawodne oparcie w różnego rodzaju życiowych sytuacjach. W ten sposób stara się on fantazmatycznie „dopełnić" brak po stronie kobiety i przekonać ją do siebie. Kobieta z kolei nakłada wobec mężczyzny maskę pięknego obiektu, który ten może zdobyć zawłaszczając w ten sposób jej „bycie” fallusem ${ }^{18}$.

W rzeczywistości mamy tu do czynienia z podziałem have/appear. Kobieta nie jest więc fallusem, ale jedynie wydaje się (appear to be) nim i tu dochodzimy do punktu, w którym kobieta jawi się nam jako złudzenie. Kobieta pragnie być kochana za coś, czym w rzeczywistości nie jest za falliczną maską nic nie ma. Kobieta oferuje siebie mężczyźnie nie jako ona sama, ale jako coś, czym nie jest ${ }^{19}$.

\section{RÓŻNICA PECIOWA}

Pojęcie różnicy seksualnej (podobnie jak to, co miało miejsce w przypadku kobiecości i zmiany definicji symptomu), wiąże się z różnymi formułami jouissance ${ }^{20}$. U Lacana mamy przejście od „męskiego” ujęcia jouissance do ujęcia „żeńskiego”. Z jednej strony mamy do czynienia z zamkniętym i solipsystycznym obiegiem popędu, który znajduje ujście - jak pisze Žižek ${ }^{21}$ - w idiotycznej masturbacji, $\mathrm{z}$ drugiej natomiast mamy do czynienia

${ }^{18}$ P. Dybel, Zagadka..., dz. cyt., s. 233.

${ }^{19}$ Zob. S. Žižek, Woman..., dz. cyt.

${ }^{20}$ "Choć jouissance przekłada się zwykle jako rozkosz, tłumacze Lacana często pozostawiają francuski oryginał, aby oddać ekscesywny, ściśle traumatyczny charakter tego terminu: nie mamy tu do czynienia z prostymi przyjemnościami, ale z gwałtownym wtargnięciem, które przynosi więcej bólu niż przyjemności. [...] odczuwanie rozkoszy nie jest kwestią podążania za spontanicznymi skłonnościami, ale raczej czymś, co robimy z dziwacznego i pokręconego poczucia etycznego obowiązku": S. Žižek, Lacan, Wydawnictwo Krytyki Politycznej, Warszawa 2010, s. 108.

${ }^{21}$ Zob. tenże, The Real of Sexual Difference, [w:] Reading Seminar XX, red. S. Barnard B. Fink, State University of New York Press, Nowy Jork 1996, s. 59. 
z podmiotami, u których dostęp do jouissance jest związany z dostępem do dyskursu Innego - do tego, w jaki sposób się o/do nich mówi. W ostatnim chodzi o satysfakcję, jaką sprawia sama mowa, a nie akt. To według Žižka uzasadnia różnice występujące w realizacji fantazji seksualnych za pomocą Internetu. Mężczyźni częściej używają cyberprzestrzeni jako urządzenia sprzyjającego samotnej masturbacji, zanurzając się w idiotycznej powtarzającej się przyjemności (immersed in stupid, idiotic pleasure), kobiety natomiast chętniej biorą udział w czatach, używając tym samym Internetu do uwodzenia za pomocą języka ${ }^{22}$.

Aby jednak ująć istotę problemu różnicy seksualnej, wystarczy spojrzeć na tytuł eseju Slavoja Žižka - The Real of Sexual Difference. Otóż różnica płciowa jest czymś realnym ${ }^{23}-\mathrm{w}$ sensie lacanowskim. To złożenie statycznych, symbolicznych opozycji, ale ślepy zaułek - coś, co opiera się wszelkim próbom symbolizacji. Każda próba przekładu na porządek symboliczny musi zakończyć się fiaskiem. Ten bowiem opiera się na własnej niewystarczalności, niemożności dopełnienia idealnego dopasowania słów do rzeczy. Niewystarczalność ta oznacza właśnie, że stosunek seksualny nie istnieje, a opozycja kobieta/mężczyzna oznacza nieudolną próbę symbolizacji. Myers pisze:

Różnica między płciami nie jest zatem prostą kwestią uznania dwóch różnych symbolicznych mandatów, których nieudane wypełnienie oznacza, że zostajemy wrzuceni do Realnego. Określenia „mężczyzna”

\footnotetext{
${ }^{22}$ Zob. tamże, s. 59.

${ }^{23}$ Lacan pisze o trzech porządkach: realnym, wyobrażeniowym oraz symbolicznym. Są to pojęcia kluczowe w psychoanalizie Lacanowskiej. „W obrębie triady wyobrażeniowe-symboliczne-realne zachodzą wszelkie relacje pomiędzy człowiekiem a nim samym, innym człowiekiem, światem i bytem. [...] Jej podstawę stanowi stadium lustra i wynikające zeń doświadczenia. Określa ona rodzaj relacji pomiędzy Ja i całością jego podmiotowego bytu a innym, która całkowicie zdominowana jest przez miłość własną i na skutek tego prowadzi do istotnego. [...] [Pojęcie symbolicznego - dop. N.M.] zawiera w sobie wszystko, co jest językiem albo posiada identyczną z nim strukturę. W tym sensie symboliczne jawi się - co do swojego wewnętrznego "porządku» - jak to, co dystansuje się wobec plątaniny wyobrażeniowych powiązań. [...] Realne jest wreszcie tym wszystkim, co pozostaje poza zasięgiem symbolicznego, jest tą strefą, w której symboliczne zawodzi, jest czymś w istocie nie-wypieralnym, identycznym z samym sobą": H. Lang, Język i nieświadomość, Słowo/obraz/terytoria, Gdańsk 2005, s. 183-184.
} 
i „kobieta” są raczej różnymi sposobami zdania sobie sprawy z porażki prób symbolizacji realności różnicy seksualnej ${ }^{24}$.

To właśnie owa niemożliwość otwiera hegemoniczną walkę o to, co różnica seksualna będzie oznaczać. Niemożliwość oznacza więc tak naprawdę pole możliwości dla wszelkich interpretacji. Stąd też różnica seksualna pojawia się $\mathrm{w}$ tak wielu sprzecznych ze sobą koncepcjach. Jak mówi Žižek w swoim wykładzie, przytaczając tytuł serialu X-files: The Truth Is Out There który wydaje się oddawać istotę realnego - to, co mówimy o sobie, jest jedynie kłamstwem, które zakrywa to, co realne ${ }^{25}$. Podobna rzecz ma miejsce w filmach pornograficznych. W nich wszystko wydaje się pokazane bez jakiejkolwiek cenzury. Jednakże, jak wspomina Žižek w tym samym wykładzie, w filmach pornograficznych jest cenzura, a jest nią minimalny i ,absolutnie głupi dialog”. Przykładem tego dialogu jest konwersacja między hydraulikiem a bohaterką filmu, trwająca zaledwie kilkadziesiąt sekund, ale pojawiająca się co jakiś czas w filmie. Pozornie pozostaje zupełnie bez znaczenia, pełni jednak funkcję podobną do kłamstwa - zakrywa to, co bez niej byłoby nie do zniesienia.

Upodmiotowienie jest niemożliwe, ponieważ istnieje tu relacja podmiotprzedmiot, co więcej relacja ta nie może zostać zniesiona. Podobnie stosunek seksualny - przez radykalną asymetrię nie można nawiązać bezpośrednich relacji między podmiotami po obu stronach. Żadna ze stron nie może zobaczyć miejsca, z którego patrzy ta druga. Co więcej, niemożliwa jest nie tylko relacja, ale samo istnienie dwóch podmiotów jednocześnie.

\section{4. „STOSUNEK SEKSUALNY NIE ISTNIEJE”, CZYLI MIŁOŚĆ}

Miłość u Slavoja Žižka pojawia się wielokrotnie. Według filozofa jest ona spowodowana niejako niemożliwością zaistnienia stosunku seksualnego, ponieważ kamufluje nieudolną symbolizację różnicy seksualnej. Myers stwierdza, że miłość jest niejako ideologią różnicy płciowej:

\footnotetext{
${ }^{24}$ T. Myers, Jakie..., dz. cyt., s. 129.

${ }^{25}$ Rzeczony wykład dla Google jest dostępny w: http://www.youtube.com/watch? $\mathrm{v}=\_\mathrm{x} 0$ eyNkNpL0 (dostęp: 7 IV 2012).
} 
W swojej najbardziej zwodniczej wersji, którą możemy znaleźć, miłości detektywa do femme fatale, przedstawia całą serię przeszkód stojących na drodze do spełnienia tego uczucia. Przeszkody te tylko zaciemniają fakt, że spełnienie, któremu zdają się stać na drodze, tak naprawdę w ogóle nie jest możliwe - ostatecznie nie da się połączyć „mężczyzny” z "kobietą”"

Žižek w swoich esejach przytacza Lacanowską definicję miłości jako „dawania czegoś, czego się nie ma”, dodając przy tym drugą część tego zdania (swoją własną): „komuś, kto tego nie chce”. Przykładem tego jest sytuacja, w której ktoś wyznaje nam namiętną miłość. W tym miejscu filozof pyta:

Czyż pierwszą naszą reakcją, nawet jeśli potem odpowiadamy na to wyznanie przychylnie, nie jest poczucie, że narzuca się nam coś obscenicznego, natrętnego? Właśnie dlatego pasja jest „politycznie niepoprawna", mimo że wydaje nam się, jakby wszystko było dozwolone, zakazy uległy tylko przemieszczeniu ${ }^{27}$.

To odsyła do koncepcji miłości obracającej się wokół różnicy seksualnej. Według słoweńskiego filozofa mężczyzna pragnie być kochany za to, kim prawdziwie jest $^{28}$, a miłość kobiety jest bezinteresowna. Žižek pisze:

A recent English publicity spot for a beer renders perfectly what Lacan aims at with his notion that "there is no sexual relation". Its first part stages the well-known fairy tale anecdote: a girl walks along a stream, sees a frog, takes it gently into her lap, kisses it, and of course, the ugly frog miraculously turns into a beautiful young man. However, the story isn't over yet: the young man casts a covetous glance at the girl, draws her towards himself, kisses her, and she turns into a bottle of beer the man triumphantly holds in his hand ${ }^{29}$.

${ }^{26}$ T. Myers, Jakie... dz. cyt, s. 130.

${ }^{27}$ S. Žižek, Hipokryzja lewicy, „Krytyka polityczna” 2005, nr 9/10, s. 253.

${ }^{28} \mathrm{Tu}$ Žižek daje przykład opowieści, w których to książę przebiera się za sługę, by upewnić się o miłości swojej ukochanej. Zob. tenże, Women..., dz. cyt.

${ }^{29}$ Tamże. 
Dla kobiety istotne jest to, że jej miłość przemienia żabę w przystojnego mężczyznę (czyli Lacanowską pełnię fallicznej obecności), dla mężczyzny natomiast istotne jest zredukowanie kobiety do obiektu. Związek jest niemożliwy tak długo, jak długo istnieć będzie relacja podmiot-przedmiot.

Innym spojrzeniem na miłość jest jego próba interpretacji fragmentu Pierwszego Listu do Koryntian świętego Pawła ${ }^{30}$. Istotne w tym fragmencie, jak zaznacza filozof, jest miejsce miłości wobec Ws zystkiego (jako całości wiedzy i proroctw). Na początku święty Paweł stwierdza, że miłość może istnieć, nawet jeżeli posiadamy c a łą wiedzę; następnie, w kolejnym para-grafie stwierdza, że jest ona dostępna jedynie niekompletnym istotom (incomplete beings). To, jak pisze Žižek, wiąże się ściśle z kobiecymi formułami diagramu różnicy seksualnej - nawet jeżeli jest w s z y st ko (kompletne, bez wyjątku), pole wiedzy pozostanie niekompletne. Nawet jeżeli posiadając całą wiedzę bez miłości, bylibyśmy niczym, to wcale nie oznacza, że posiadając miłość, jesteśmy „czymś”. W miłości także jesteśmy niczym, ale Niczym świadomym swojego braku. Jedynie wybrakowana i bezbronna istota jest zdolna do miłości, zatem największą tajemnicą miłości jest według Žižka fakt, że owa niekompletność stoi wyżej niż pełnia. Miłość jest zatem dogłębnie kobieca - uwzględnia bowiem paradoks nie-Wszystkiego $(\text { braku })^{31}$.

Ostatnią już interpretacją, jaką przytoczę, jest koncepcja miłości dworskiej. Dama z miłości dworskiej, jak pisze filozof, „nie ma nic z dzisiejszej kobiety - jest ona tylko narcystyczną projekcją mężczyzny i oznacza uśmiercenie kobiety z krwi i kości" ${ }^{32}$. Miłość dworska opiera się jedynie na etykiecie i kurtuazji, nie ma w niej namiętności - dama jest całkowicie niedostępna i z tej perspektywy miłość ta jawi się jako najbardziej radykalna strategia nakierowana na podniesienie wartości obiektu poprzez stawianie konwencjonalnych przeszkód na drodze do jego osiągnięcia ${ }^{33}$. Owa strategia ma jedynie tworzyć pozór, że gdyby tych przeszkód nie było, to obiekt

${ }^{30}$ Zob. 1 Kor 13, 1-13, korzystałam z wyd. 4 Brytyjskiego i Zagranicznego Towarzystwa Biblijnego.

${ }^{31}$ Zob. S. Žižek, The Real.., dz. cyt., s. 60-61.

${ }^{32}$ Tenże, Miłość dworska czyli kobieta jako Rzecz, [w:] Žižek. Przewodnik krytyki..., dz. cyt., s. 259.

${ }^{33}$ Zob. tamże, s. 264. 
byłby bezpośrednio dostępny. Za przykład posłużyć mogą filmy Louisa Bunuela - w Mrocznym przedmiocie pożadania kobieta w nieskończoność odkłada moment seksualnego zespolenia (gorset z licznymi wiązaniami), cały film natomiast obraca się wokół tegoż właśnie napięcia. Zdaniem Žižka mamy tu do czynienia z miłością dworską czystej postaci, gdzie codzienny przedmiot/akt staje się niedostępny, ponieważ przyjął postać Rzeczy. Podobnie w Dyskretnym uroku burżuazji dwie pary chcą zjeść obiad, ale niespodziewane komplikacje im to uniemożliwiają. Tak więc mamy tu do czynienia $\mathrm{z}$ zupełnie inną koncepcją niż ta obecna w interpretacji świętego Pawła.

Późniejsza wersja miłości dworskiej to przede wszystkim femme fatale w filmach noir. Tu kapryśna kobieta-Rzecz doprowadza do ruiny głównego bohatera. Istotna jest tu obecność tego trzeciego - czarnego charakteru, który posiada femme fatale, i tym samym mamy do czynienia z taką samą niedostępnością i transgresją. Zadając się z damą, bohater dopuszcza się zdrady iście ojcowskiej. Istotne, że femme fatale tylko pozornie różni się od damy omawianej wcześniej. W gruncie rzeczy jednak traumatyczny wpływ jest taki sam - zarówno dama, jak i femme fatale są „nieludzkimi partnerami”, obiektami czy Rzeczą, z którymi związek jest niemożliwy ${ }^{34}$.

Ale czym/kim właściwie jest Dama? Jak pisze Žižek: „Dama nie jest kolejną nazwą dla metafizycznej podstawy wszystkiego, lecz, przeciwnie, jedną z nazw oznaczających samo wycofujące się Realne, które w pewien sposób ugruntowuje Realne, które w pewien sposób ugruntowuje samą podstawę"35. I tak ile Podstawę wszystkiego możemy nazwać „najwyższym Dobrem”, o tyle Dama jako Rzecz jest ucieleśnieniem zła. Sama miłość dworska jest sposobem na uniknięcie związku, zaangażowania czy seksualnej relacji. Podobnie ma się rzecz z fałszywą miłością - idea, że świat nie jest dla nas, że tylko gdybyśmy żyli w innym czasie moglibyśmy napotkać prawdziwą miłość, gdyby tylko okoliczności były korzystne. Tak naprawdę jest to kolejny sposób na uniknięcie zaangażowania ${ }^{36}$.

\footnotetext{
${ }^{34}$ Zob. tamże, s. 278.

${ }^{35}$ Tenże, Conversations with Žižek, Polity, Cambridge 2004, s. 71.

${ }^{36}$ Zob. tenże, Miłość dworska..., dz. cyt., s. 272.
} 


\section{FEMINIZM I KRYTYKA}

Judith Butler w pracy napisanej wraz ze Slavojem Žižkiem i Ernesto Lac$\mathrm{lau}^{37}$ zadaje pytanie naszemu bohaterowi, czy - w obliczu tego, co powiedzieliśmy już o różnicy seksualnej, czyli o niemożliwości jej symbolizacji feminizm jest ślepą uliczką, tłumacząc jednocześnie, że jeżeli pozostaje ona w sferze Realnej, to czy nie zostanie uznana za istotową i tym samym niemożliwą do zmiany. Wówczas bowiem każda poprawa sytuacji kobiet, w ogóle walka czy jakakolwiek zmiana byłaby oskarżana o atak na pewien stan natury. Žižek, odpowiadając na te wątpliwości, wyjaśnia, że porządek Realnego nie ma charakteru uprzedniego wobec tego, co Symboliczne. Prawdopodobnie jest wręcz przeciwnie, Realne jest związane z porażką Symbolicznego. A ponieważ symbolizacja jest historycznie zmienna, to feminizm nie jest tylko nieudaną próbą zmiany czegoś, czego nie da się zmie$n^{c^{38}}$. Realne zatem nie ma i nie może mieć charakteru esencjalistycznego.

Między innymi w dyskusjach z Judith Butler, ale także w innych analizach, nie widać postawy antyfeministycznej, lecz co najwyżej fallocentryczną. To ostatnie oznacza przede wszystkim, że dyskusje Žižka na temat kobiet obejmują odkrywanie mechanizmów czy fantazmatycznej realności, która leży u podłoża pewnego stanu rzeczy, jak np. zła sytuacja kobiet ${ }^{39}$. Według słoweńskiego filozofa nie istnieją normy, wedle których można oceniać ludzi. Pisze:

Nie jest tak, że homoseksualiści, fetyszyści i inni zastępują normatywny fakt, że istnieje różnica seksualna - nie są oni dowodami na porażkę różnicy seksualnej w próbie narzucenia własnych norm; nie chodzi o to, że różnica seksualna jest ostatecznym punktem odniesienia, kotwicą dla przygodnie dryfujących seksualności. Raczej na odwrót, świadczą oni o nieusuwalnej luce istniejącej między Realnym różnicy seksualnej, a określonymi formami heteroseksualnych norm symbolicznych, w której mieści się wiele „perwersyjnych” form seksualności ${ }^{40}$.

${ }^{37}$ Zob. J. Butler, E. Laclau, S. Žižek, Contigency, Hegemony, Uniwersality. Contemporary dialogues on the left, Verso, Nowy Jork 2000, s. 6.

${ }^{38}$ Zob. T. Myers, Jakie..., dz. cyt., s. 128.

${ }^{39}$ Zob. K. Ror Malone, Female..., dz. cyt., s. 2.

${ }^{40}$ S. Žižek, The Ticklish Subject, Londyn 2000, s. 273, cyt. za: T. Myers, Jakie..., dz. cyt., s. 129. 
Oznacza to przede wszystkim elastyczność teorii, którą prezentuje nam w swych pracach Slavoj Žižek. Bo czy nie rozwiązuje to problemu zbyt ostrego (a może wręcz zbędnego?) podziału różnicy seksualnej i wskazuje na ograniczoność języka, na którą tak narzekają twórcy teorii feministycznych i queerowych?

O ile jego teorie niewątpliwie kontynuują fallogocentryczny dyskurs panujący w psychoanalizie, to jednak nie można nie zauważyć potencjału kryjącego się za jego interpretacjami oraz przydatnością narzędzi, które służyć mogą krytyce i późniejszemu obaleniu patriarchalnego i heteronormatywnego porządku rzeczywistości. 